\title{
Chapter 10 \\ Nature-Based Solutions and Buildings - The Power of Surfaces to Help Cities Adapt to Climate Change and to Deliver Biodiversity
}

\author{
Vera Enzi, Blanche Cameron, Péter Dezsényi, Dusty Gedge, Gunter Mann, \\ and Ulrike Pitha
}

\begin{abstract}
By 2020, according to United Nations and European Union reports, $75 \%$ of Europe's population will be living in cities - that's around 365 million citizens. The majority of our cities are hot, dry, polluted and impermeable and increasingly densely populated. The pressure for new development means hard, impermeable surfaces are replacing urban green space and natural habitats. At the same time, climate change is bringing more frequent and extreme weather events such as summer storms, flash flooding and heatwaves.

New developments must be resilient. But we also need to retrofit our existing building stock - to adapt to the impacts of climate change. This challenge is also a
\end{abstract}

\footnotetext{
V. Enzi $(\bowtie)$

Austrian Greenroof and Livingwall Association VfB- GRÜNSTATTGRAU, Vienna, Austria

European Federation of Green Roof and Wall Associations EFB, Vienna, Austria

The Urban Green Infrastructure Competence Centre, Green4Cities GmbH, Vienna, Austria e-mail: vera.enzi@gruenstattgrau.at

B. Cameron

Bartlett School of Architecture, University College London, London, UK

e-mail: becameron@hotmail.co.uk

P. Dezsényi

Hungarian Greenroof and Livingwall Association ZEOSZ, Budapest, Hungary

Deep Forest Kft., Budapest, Hungary

e-mail: pdezsenyi@deepforest.hu

D. Gedge

European Federation of Green Roof and Wall Associations EFB, Vienna, Austria

Livingroofs Enterprises Ltd, London, UK

The Green Infrastructure Consultancy Ltd, London, UK

e-mail: dusty@dustygedge.co.uk 
chance - to green cities and to create habitats for species which in turn provide us with the ecosystem services and benefits cities will rely on for health, well-being and prosperity through the twenty first century. When designed in an integrative and inclusive way, nature-based solutions such as green roofs, green walls, rain gardens, street trees and other urban green infrastructure generate a wide range of benefits.

As well as providing habitats for species, urban greening helps to keep cities cool during summer heat waves, reducing the Urban Heat Island Effect, to manage surface water flooding due to heavy rains and to improve air quality. Green infrastructure also offers an attractive economic Return On Investment (ROI) and a range of other benefits to society, such as connection with nature, and mental and physical health. High quality green infrastructure can also reduce noise pollution, a major cause of stress for city dwellers. Greening a building can help cut heating and cooling costs too, saving energy and other resources. Green cities give better quality of life, meaning healthier, happier citizens, higher productivity at work and a reduction in absence from work due to illness.

This paper focuses on the microclimate benefits of integrating high quality green infrastructure as part of adapting cities to climate change. It estimates market potential and related factors such as energy use, evapotranspiration and water management. It explains through best practise examples how green roofs and green walls designed for nature can contribute to urban biodiversity networks. And it shows how twenty first century nature-based cities can be natural, healthy and resilient.

Keywords Green infrastructure - Nature based solutions • Living walls • Green walls $\bullet$ Green roofs $\bullet$ Raingardens $\bullet$ Permeable surfaces $\bullet$ Urban heat island mitigation $\bullet$ Flood risk reduction $\bullet$ Quality of life $\bullet$ Health and social benefits $\bullet$ Re-naturing cities $\bullet$ Urban retrofit $\bullet$ Biodiversity $\bullet$ Energy $\bullet$ Rainwater management $\bullet$ Climate change resilience $\bullet$ Return of invest $\bullet$ Ecosystem services $\bullet$ Ecosystem disservices $\bullet$ Air quality $\bullet$ Noise reduction

\footnotetext{
G. Mann

Optigrün International AG, Krauchenwies, Germany

Fachvereinigung Bauwerks Begrünung - FBB, Saarbrücken, Germany

e-mail: gunter.mann@t-online.de

U. Pitha

University of Natural Rescources and Life Sciences Vienna BOKU, Institute of SoilBioengineering and Landscape Construction, Vegetation Engineering Group, Vienna, Austria

The Urban Green Infrastructure Competence Centre, Green4Cities GmbH, Vienna, Austria e-mail: ulrike.pitha@boku.ac.at
} 


\subsection{Greening the Urban Market: Now We're Growing!}

By 2020, 75\% of Europe's population will be living in cities - a total of about 365 million citizens (United Nations 2014). Urban environments are becoming increasingly dense with ever more demand on space for development. The majority of our cities are hot, dry, polluted and impermeable. Pressure for new development means hard, impermeable surfaces are replacing urban green space and natural habitats. At the same time, climate change is bringing more frequent and extreme weather events such as summer storms, flash flooding and heatwaves (EEA 2012).

New developments must be resilient. But we also need to retrofit our existing building stock - to adapt to the impacts of climate change. This challenge is also a chance - to green cities and to create habitats for species which in turn provide us with the ecosystem services and benefits cities will rely on for health, well-being and prosperity through the twenty first century. Cities are growing, but it is in our hands to grow them in a green, sustainable and resilient way.

Most current business forecasts predict that Europe will continue to grow physically and in market terms, and will remain an attractive global trading partner. Therefore, expanding sectors such as innovation and employment is an essential part of European politics (European Commission 2012).

The European Commission also recognizes the value of ecosystem services, the benefits provided by green infrastructure such as green roofs, green walls, rain gardens, street trees parks, gardens and more. In 2013, the Commission published its Green Infrastructure Strategy, Europe's Natural Capital (European Union 2013), followed by a research and innovation policy agenda for nature-based solutions \& renaturing cities (European Commission 2015) and the final Report on Supporting the Implementation of Green Infrastructure (European Commission 2016a) (Fig. 10.1).

How are businesses and commercial success linked to Europe's urban green infrastructure agenda? Even at a conservative estimate, the green roof industry produces promising figures. The most detailed market report comes from Germany. The German market, along with Switzerland and Austria, is the most mature and therefore has the most accurate data. Up to 2015, 86 million $\mathrm{m}^{2}$ of green roofs (see Table 10.1) had been installed in Germany and many flat roofs are already greened (EFB 2015).

Since 2008, The German Green Roof and Wall Association (Fachvereinigung Bauwerksbegrünung FBB) has been constantly monitoring trends that show a market increasing by an average of $5 \%$ per year. Across Austria, Switzerland and Germany, a minimum of 10.3 million $\mathrm{m}^{2}$ of green roofs are installed each year, driven by regulations and policies and the efforts of around 200 small to medium sized enterprises (EFB 2015).

Outside these three main European markets, several other cities, such as London, Rotterdam and Paris, are showing significant increases in the installation of green roofs particularly driven by policy (e.g., Greater London Authority 2008).

The majority of companies involved in the green roof industry also have the knowledge and skills to contribute to the internal and external vertical greening of our building stock (EFB 2015). 


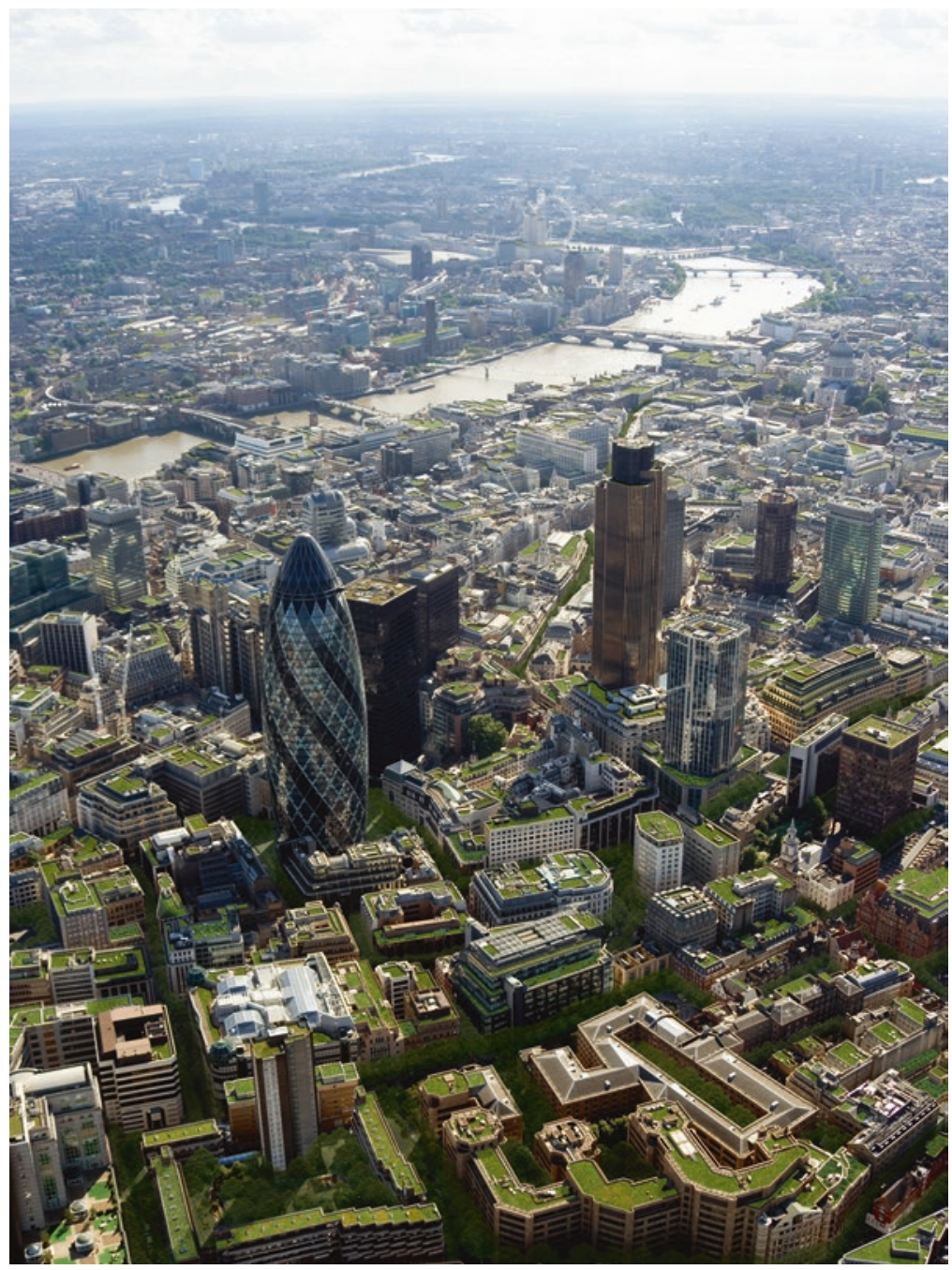

Fig 10.1 Green design for Londons Roofs (Source: Arup, on behalf of the London Sustainable Development Commission)

Independent market research estimates $2017 \mathrm{~s}$ vertical greening market at 680 million Euros, a figure equating to the installation of around 1 million $\mathrm{m}^{2}$ of green walls (Caroles 2015). Further, aside from the capital market, the revenue market associated with building vegetation maintenance is also set to increase, providing long-term, secure and sustainable new jobs.

Currently, concern over green infrastructure maintenance costs such as for green roofs is a perceived barrier to faster uptake. Comparisons however show that maintenance costs for vegetated envelopes on buildings are not actually significantly higher than those of comparable conventional building envelopes, such as a glass 
Table 10.1 Trends in European green roof market

\begin{tabular}{l|l|l|l|l|l}
\hline Target country & $\begin{array}{l}\text { Green roof } \\
\text { stock total } \mathrm{m}^{2} \\
(2014)\end{array}$ & $\begin{array}{l}\text { Green roofs } \\
\text { new/year } \mathrm{m}^{2}\end{array}$ & $\begin{array}{l}\text { Ratio } \\
\text { extensive } \\
\%\end{array}$ & $\begin{array}{l}\text { Ratio } \\
\text { intensive } \\
\%\end{array}$ & $\begin{array}{l}\text { Yearly sales } \\
\text { figures } €\end{array}$ \\
\hline Austria & 4.500 .000 & 500.000 & 73 & 27 & 27.350 .000 \\
\hline Germany & 86.000 .000 & 8.000 .000 & 85 & 15 & 254.000 .000 \\
\hline Hungary & 1.250 .000 & 100.000 & 35 & 65 & 5.662 .500 \\
\hline $\begin{array}{l}\text { Scandinavia } \\
\text { S, N, DK) }\end{array}$ & & 600.000 & 85 & 15 & 16.050 .000 \\
\hline Switzerland & & 1.800 .000 & 95 & 5 & 51.300 .000 \\
\hline UK & 3.700 .000 & 250.000 & 80 & 20 & 28.000 .000 \\
\hline & 95.450 .000 & 11.250 .000 & & & 382.362 .500 \\
\hline
\end{tabular}

Trend: growing (FBB DE)

Source: European Federation of Green Roofs and Walls - EFB 2015

facade compared to a green wall (Pfoser 2013). With green roofs, once reduced energy demand and a longer life expectancy of the envelope are taken into account, the overall cost benefit calculation becomes positive (Hämmerle and EFB 2007).

As green roofs and walls are intrinsic nature-based solutions they also have the potential to quantitatively and qualitatively improve biodiversity at a local and regional level. This improvement will be dependent on the design and systems used but has already been realised in several cities in Europe at the building level (EFB 2015).

\section{2 “Green" Versus “Grey" Solutions for Climate Change Adaptation and Mitigation}

\subsubsection{Extreme Weather - Excess Heat Events and Energy}

Today, cities provide homes to $50 \%$ of the world's population on just $2 \%$ of the Earth's surface (United Nations 2014). At the same time, cities are responsible for $80 \%$ of global $\mathrm{CO}_{2}$ emissions and two thirds of world energy consumption (UNEP 2016). Today, buildings are responsible for $40 \%$ of European energy consumption and $36 \%$ of $\mathrm{CO}_{2}$ emissions (European Commission 2016b). Energy efficiency could clearly have a major positive impact and is an integral part of European climate change mitigation policy.

Energy demand for heating and especially cooling is still on the increase worldwide, due to increased development and more extreme climate conditions (Pfoser 2013). In fact, during the European heat wave of summer 2003, nearly 70,000 European citizens died from heat-related stress (Robine et al. 2007).

This clearly shows the danger of sealed urban surfaces and "grey" densification, resulting in increased Urban Heat Island Effect (UHIE). With an increase in the UHIE, there is a general increase in energy consumption because of the increased need for cooling. We can control the internal temperature of some of our buildings 
Fig. 10.2 "Cool" facades in Europe's capitals (Source: Vera Enzi)

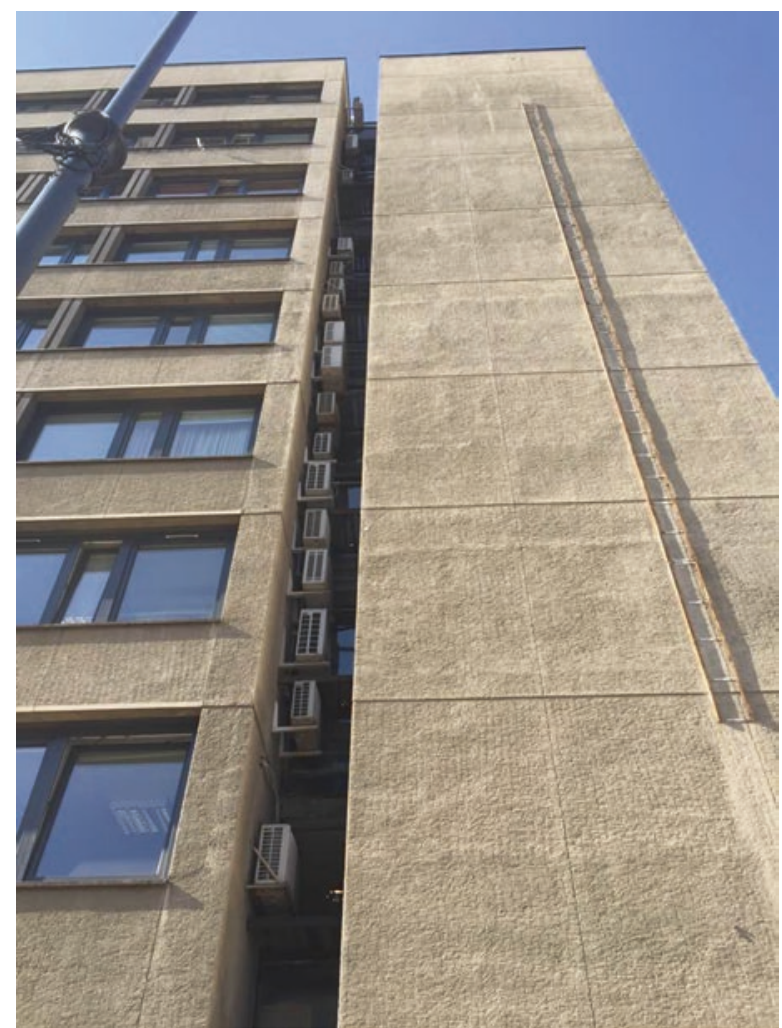

through cooling units yet this can be energy inefficient, leading to the release of more greenhouse gases into the atmosphere which in turn intensifies climate change. Furthermore, this does not protect the most vulnerable in our society: the very young or old, the sick and the financially vulnerable who cannot afford air conditioning units for their home. Increasing the supply of air conditioning units is unlikely to lead to sustainable or long-term energy efficiency. Furthermore, with increasing extreme heat events, the current reflective surfaces of cities only add intensity to these events.

There is a direct link between energy efficiency and reduction in the Urban Heat Island. Nature-based solutions such as green roofs and walls (see Fig. 10.2) can have a positive impact on ameliorating the Urban Heat Island and therefore help to increase energy efficiency, explained in detail in Chap. 3, below.

\subsubsection{Urban Flooding}

Most European cities also face another extreme weather threat: heavy rain. Stormwater incidents are leading to severe infrastructure-related financial losses and property damage (European Climate Adaptation Platform, Case Study Copenhagen 
2016). Pressure to find solutions is placed mostly on the public sector. Cities often do not fully recognize or exploit the urban environment's potential to help manage rainwater. "Grey" drainage solutions are often optimised to drain water away from urban areas as quickly as possible (see also Davis and Naumann, this volume).

Climate change not always leads to changes in the overall amount of precipitation but often to changes in rainfall patterns. Rainwater falls more heavily and in more concentrated time periods, with months of drought between. So even though our urban environments receive a high level of heavy precipitation, it is drained away very effectively, requiring compensatory activity such as irrigation technology for urban vegetation during times of drought.

It is not just vegetation that needs water. The city itself also needs to keep water in the urban climate cycle to help reduce the UHIE (Magistrat der Stadt Wien 2015) and maintain healthy levels of humidity. This linkage leads to the conclusion that goals to reduce the Urban Heat Island Effect AND stormwater resilience goals overlap.

\subsubsection{Linkages Between Water and Energy}

Energy never disappears. Heat does not stop at the building envelope. Solar radiation, wind intensity and direction, building materials, trees, plants and soil help determine urban microclimate conditions. Solar energy absorbed and reflected by mineral and insulated, single-beneficiary urban surfaces, along with the heat/energy emitted by air conditioning units, contribute to ever hotter city environments. We have to consider a city's energy balance and energy efficiency from an integrated perspective.

The basic precept is that nature-based solutions and permeable surfaces (essentially soil, water and plants) transform heat/energy. The cooling evapotranspiration by vegetation and soil help regulate surrounding microclimates - this is why water is required. Thus, blue and green infrastructure form a unit to provide ecosystem services to the urban microclimate. By implication, if we can prevent a building envelope heating up, less energy will be needed to cool the inside (Verband für Bauwerksbegrünung 2013; Pitha 2015).

Nature-based solutions offer the opportunity to rewire the city to help overcome many of the issues faced due to climate change ensuring cities become more resilient. Conventional surfaces are protective - yet they lack the multitude of other benefits and services green infrastructure can supply. Green surfaces, as shown in an implemented Pilot Project of Green Roofs and Walls for Zero-Emission (see Fig. 10.3) are the alternative as will be further elaborated on in the following sub-section.

\subsection{The Power of Surfaces - Changing the Urban Skin to Green}

In comparison with conventional building surfaces, vegetated surfaces have a living relationship to the weather. When solar radiation hits plants, they start to photosynthesise. Plants absorb $\mathrm{CO}_{2}$ and oxygen is produced. But that's not all - plants 


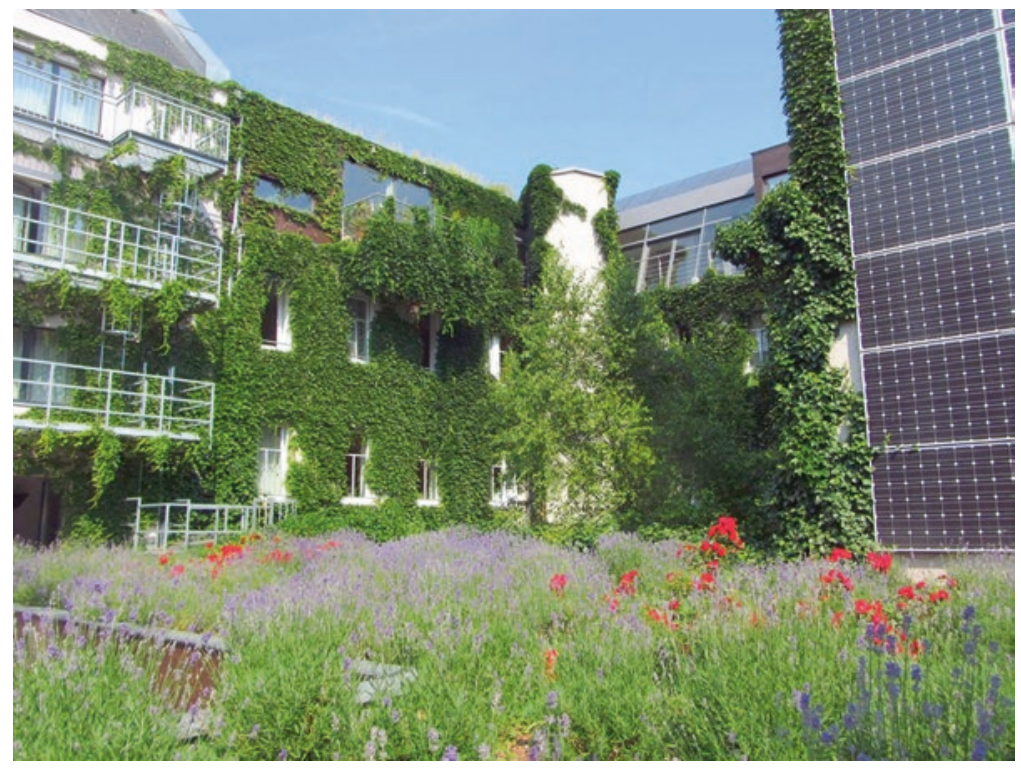

Fig. 10.3 Zero-emission Boutique Hotel Stadthalle, Vienna (Source: Michaela Reitterer)

also evapo-transpirate, they "sweat". Accumulated moisture is evaporated into the environment, helping to regulate humidity and temperature.

As with the evaporation effects of soils and substrates, these plant processes need energy to transform water from a liquid into a gas. This energy is extracted from the environment, cooling the surroundings. But the plant does not just cool the environment, it also cools itself. The surface temperature of a leaf for example will never exceed the surrounding air temperature, thus causing very little sensible heat radiation. By comparison, sheet metal and black roofs can reach over 80 ${ }^{\circ} \mathrm{C}$ on a hot summer day (Verband für Bauwerksbegrünung 2013). A third positive impact is the increase in air humidity. Thus, evapo-transpirating plants and substrates can contribute considerably to human comfort in urban environments during periods of heat excess.

Multiple research results show that plants increase their cooling effects as air temperatures increase. A living wall of $850 \mathrm{~m}^{2}$ on a public building in Vienna (see Fig. 10.4) on a hot summer day shows cooling equal to more than 80 air conditioning units of 3000 Watts each over an 8 hour operating period - a total of 712kWh (Scharf et al. 2012). This living wall also produces enough oxygen for 40 people per day (Magistrat der Stadt Wien 2017) - comparable to four 100 -year old Fagus trees. It shows the potential of living walls in places where space constraints do not allow conventional approaches to greening - for example planting trees. 
Fig. 10.4 Living wall in Vienna, Municipality Building 48 (Source: Vera Enzi)

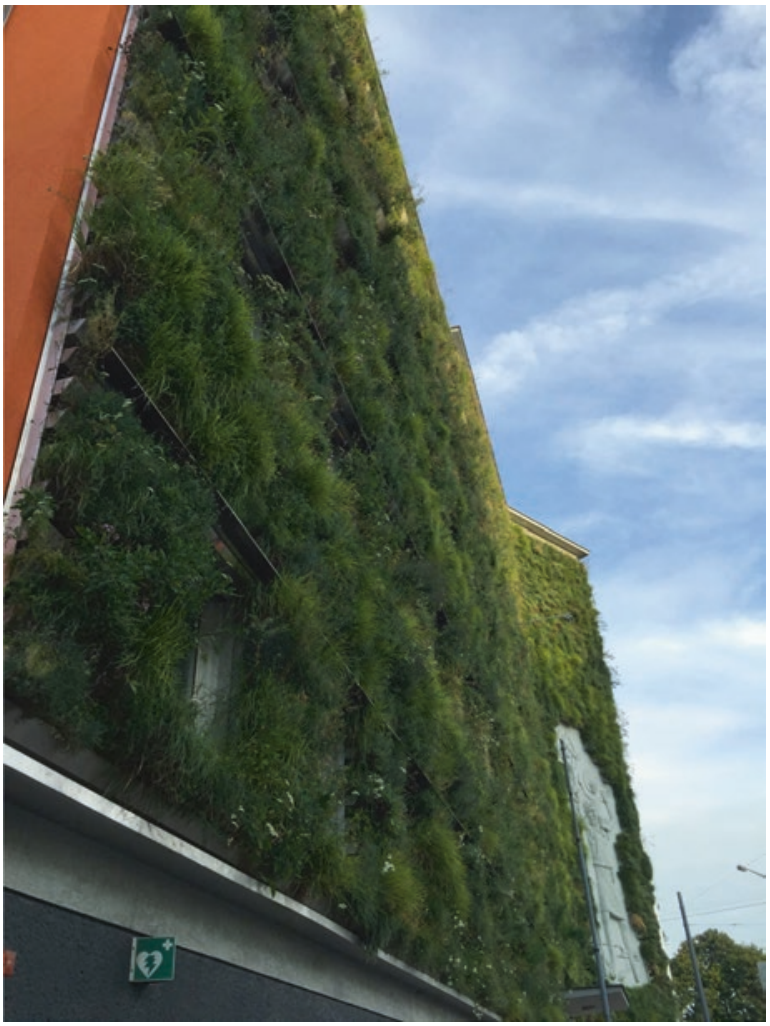

\subsubsection{Multiple Benefits of Green Walls and Roofs}

There are many reasons to invest in green infrastructure technologies such as green roofs and walls, although public and private sector motivations can differ. The public sector tends to favour investment that benefits public sector challenges, such as the Urban Heat Island Effect, urban microclimate issues, stormwater and rainwater management, air quality, ground and air transport noise, fine particulate air pollution, recreation and community activities, social cohesion, health and biodiversity issues. Figure 10.5 by Pfoser and Jakobs AG (2013) clearly shows different applications of greenery on building and the linked benefits for public and private sectors.

Studies show that intensive green roofs and especially living walls can provide a valuable service, dissolving Urban Heat Island hotspots in dense urban areas because they can change the energy regime at street level. Simulations show a reduction of PET (Physiological Equivalent Temperature, a measure of human comfort) of up to $-13{ }^{\circ} \mathrm{C}$ (Verband für Bauwerksbegrünung 2013).

Living walls can also reduce noise pollution by between 1 and $10 \mathrm{~dB}$ and green roofs especially can buffer noise pollution from air traffic sources (Pfoser 2013). Climbing plants such as Ivy (Hedera helix) and Veitchii (Parthenocissus tricuspidata) 


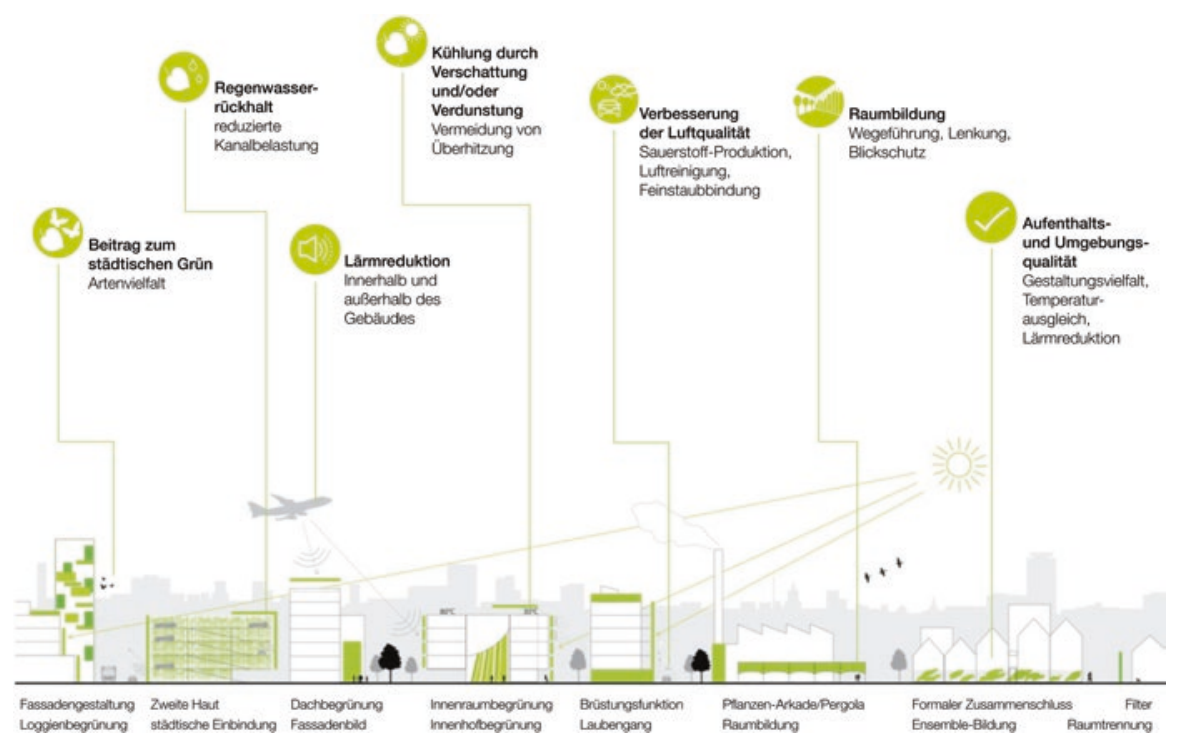

Fig. 10.5 Reasons to green buildings/Motivation Gebäudebegrünung (Source: Pfoser and Jakobs AG 2013)

can bind $1.7 \mathrm{~kg} / \mathrm{m}^{2} / \mathrm{a}$ of urban fine particulate pollutants on their leaf surfaces (Thönessen 2002, 2006; Ottelé 2011).

Numerous different citizen engagement projects all over Europe show that urban green spaces play a vital role in the sustainable development and cohesion of our society. Green roofs at ground and other levels can serve as versatile urban gardening and recreation landscapes. An excellent example is an $800 \mathrm{~m}^{2}$ large green roof in Paris, Gymnasium Deshaye that since its creation has become the focal point for the community (see Fig. 10.6) and was implemented in line with the Greening Programme of the Paris Mayors Office (Direction des espaces verts 2014).

Many different studies around the globe at city and national scales indicate that professional urban farming and agriculture will soon be moving into our cities and onto our buildings (e.g., Mann 2016; Orsini et al. 2014) (see Figs 10.7 and 10.8).

The next generations are learning about urban nature and biodiversity. Green Roofs and Living Walls providing public access serve as good examples.

\subsubsection{Green Building Technology as an Attractive Investment}

As the vast majority of urban buildings are in private ownership, the building-related benefits of green infrastructure investment are crucial. Private investment is usually based on financial benefits, for example cost savings in utilities such as heating and cooling, increased property values (Government of the Netherlands 2013) and the extended lifespan of building materials (Pfoser 2013). 


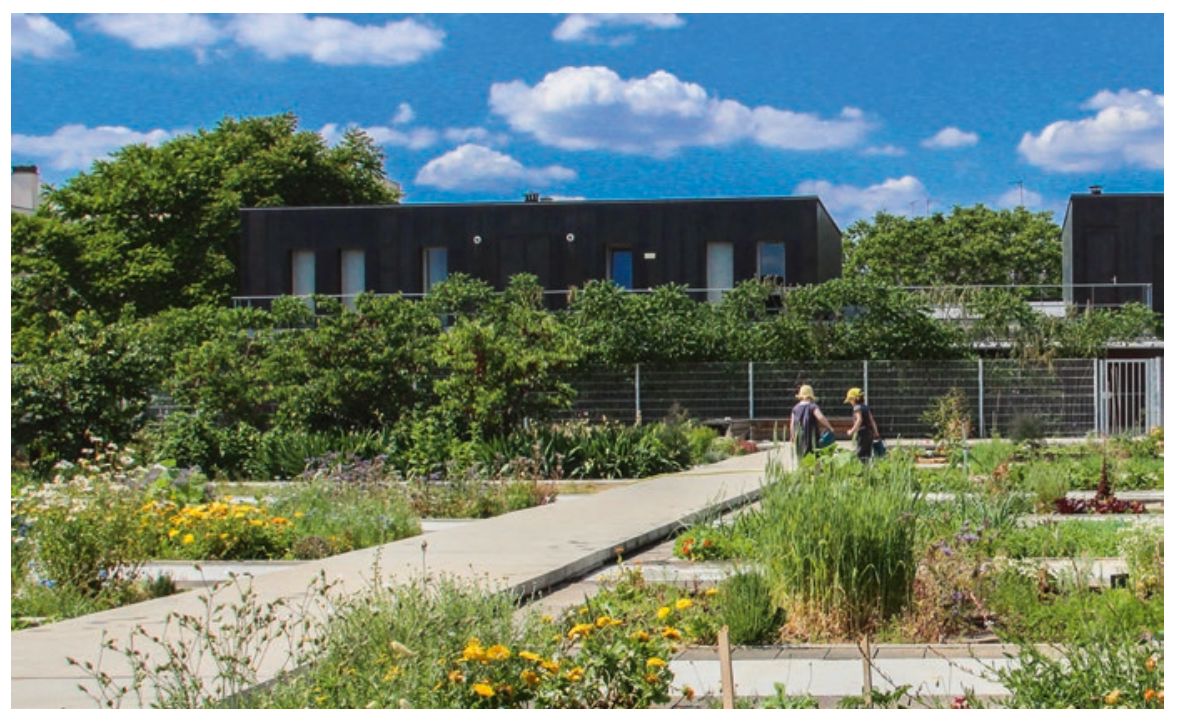

Fig. 10.6 Gymnasium green roof in Paris (Source: Dusty Gedge)

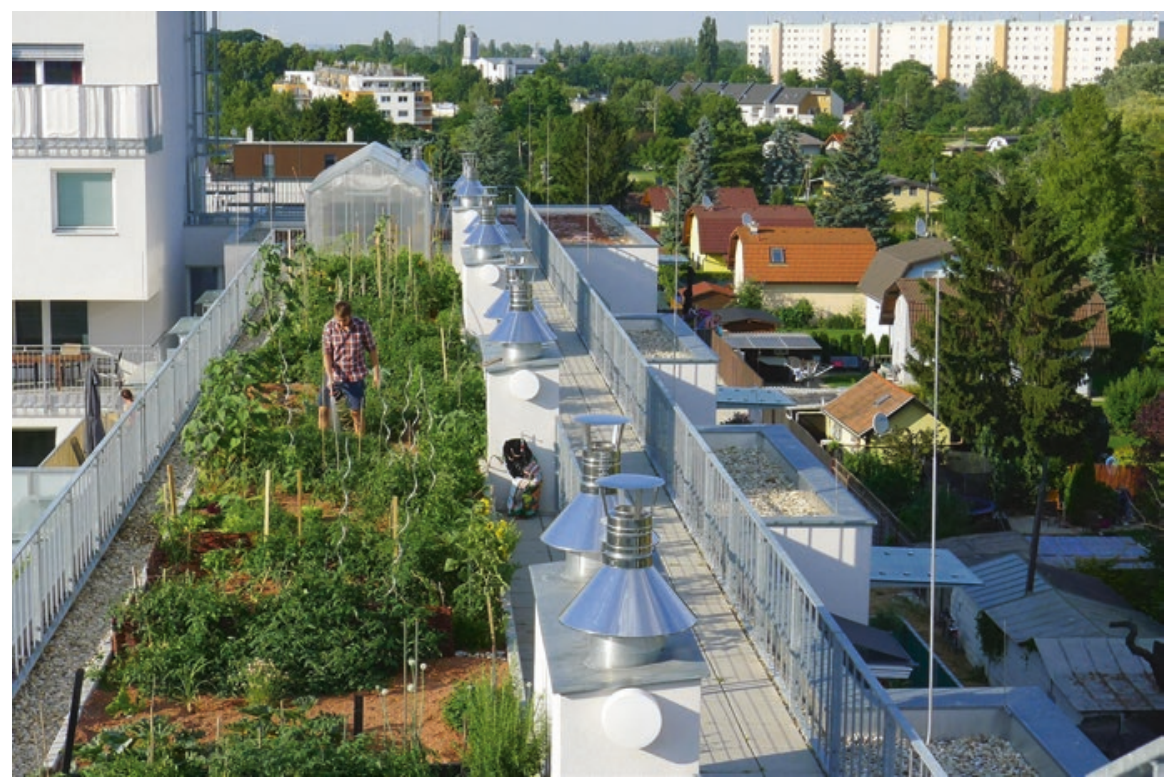

Fig. 10.7 Urban gardening roof "Oase22", Vienna (Source: VfB) 


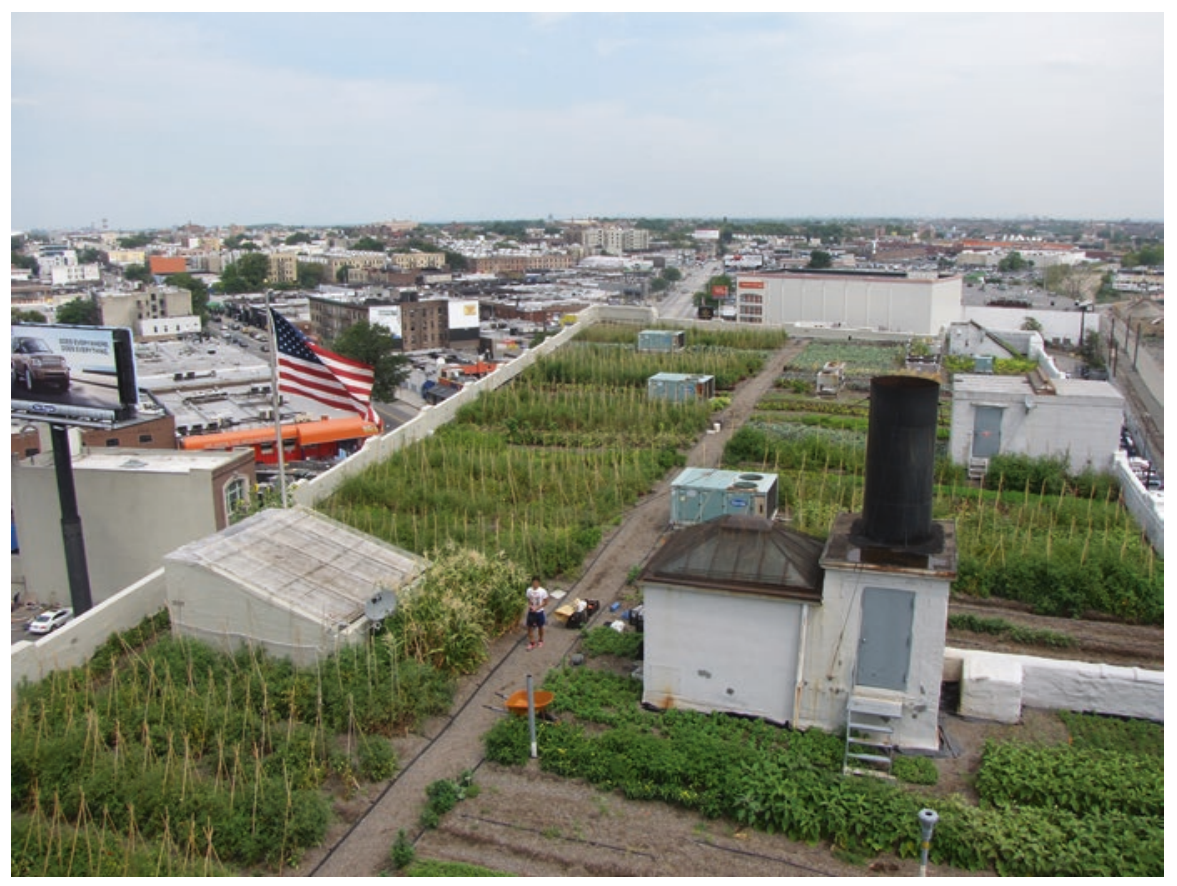

Fig. 10.8 Urban farming roof in the US (Source: Gunter Mann)

Tax incentives especially can have a major impact on green investment on roof level, as the intelligent model of split waste water tax (GAG) in Germany has demonstrated (FBB 2016). The strategy encouraged private property owners to manage their rainwater in a decentralized manner - on their own property. It effectively shared the responsibility of a public sector challenge with private property owners (FBB 2016). An improved extensive to semi-intensive green roof can hold up to 137 $1 / \mathrm{m}^{2}$, a value comparable to one full standard bathtub. In heavy rain, the public drainage system is discharged. The retained water re-enters the urban climate cycle via evapotranspiration, and the substrate and vegetation turn the water into biomass and clean, cool air (Verband für Bauwerksbegrünung 2013).

Compared to installing a gravel roof, this is an easy business case for property owners (Pfoser 2013). Their Return On Investment (ROI) is increased, payback time is reduced significantly and they can profit from additional, building-related benefits like cost savings in heating and cooling energy and the extended lifespan of their property. As an example, the building's envelope especially is exposed to extreme temperatures, causing material damage, leading to recurring renovation costs. Green roofs and walls act as buffers for extreme temperatures. The maximum daily material temperature variation of a bitumen roof is $63{ }^{\circ} \mathrm{C}$, compared to a simple extensive green roof with $19^{\circ} \mathrm{C}$ variation. Heat transfer into the building is slowed down or blocked out significantly, and the internal temperature of rooms under a green roof can be $3-4{ }^{\circ} \mathrm{C}$ less than the reference (Köhler 2012). The thicker the vegetation and substrate layer the greater the impact (Verband für Bauwerksbegrünung 2013). 
Fig. 10.9 Green wall takes on the function of external shading. Retrofitted building from the 60 ies. MA 31 Vienna (Source: Vera Enzi)

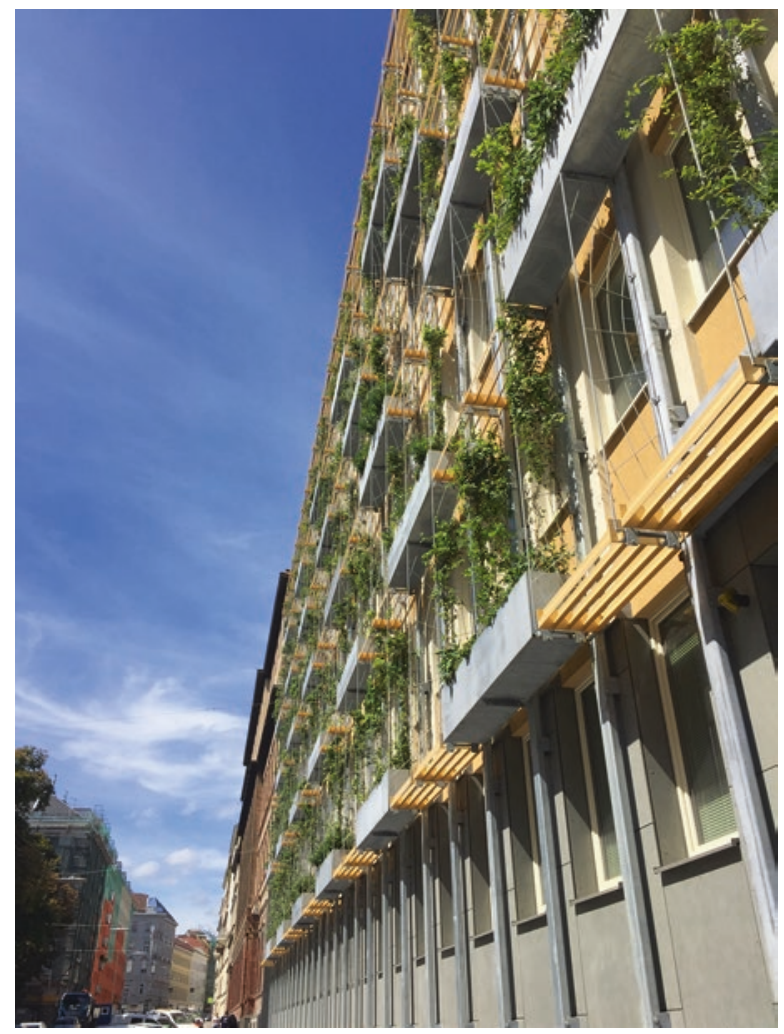

The maintenance costs of extensive and semi-intensive green roofs are comparatively low, less than $€ 17 / \mathrm{m}^{2}$ for green roofs over $1000 \mathrm{~m}^{2}$ for 40 years of maintenance (Hämmerle and EFB 2007).

Living walls and climbing plants can even replace other costs by taking on the role of technical wall system parts such as external shading elements (Pfoser 2013). The Faculty of Physics at Technical University of Berlin Adlershof (installed in 2008) and the Municipality Building 31, Vienna Water (installed in 2015, see Fig. 10.9) provide all their summer external shading needs with vegetation. In winter, the leaves fall and the buildings profits from warming sun energy.

Some experts think, that the shading effects of living walls result in higher heating costs during winter. A detailed analysis by the Technical University of Vienna in 2015 showed the opposite: Living wall systems and climbers can reduce energy transmissions in winter by a minimum of 20\% (Korjenic and Tudiwer 2016). Energy transmissions are reduced by up to $0.19 \mathrm{~W} / \mathrm{m}^{2}$ (Scharf et al. 2012).

Urban space is a scarce resource. Especially at roof level, green space is still less valued than other technologies competing for space, encouraged by financial incentives and policies, such as solar electric and solar hot water systems. However, green roofs and energy generation work very well together (see Figs 10.10 and 10.11). Some European system suppliers already offer them as a single unit. The green roof 


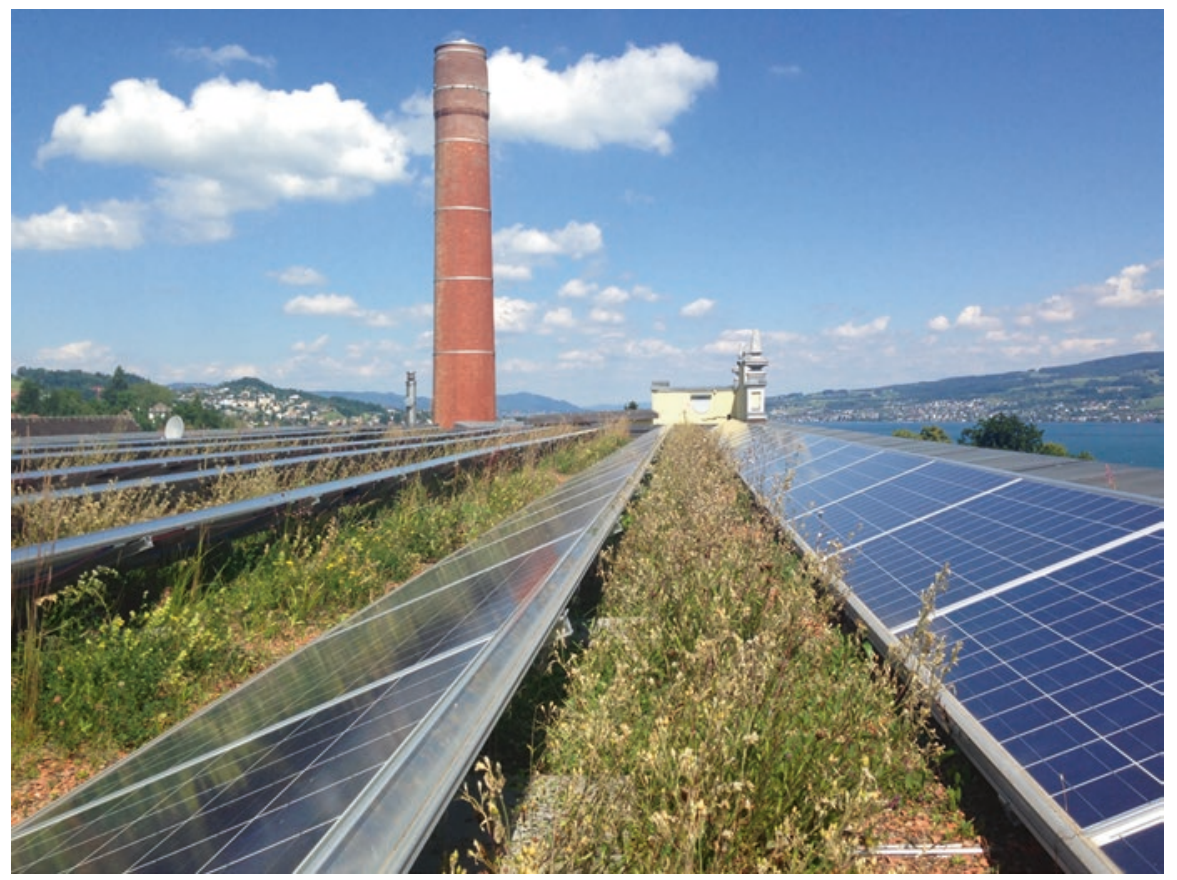

Fig. 10.10 Energy generation and green roofs in Switzerland (Source: Dusty Gedge)

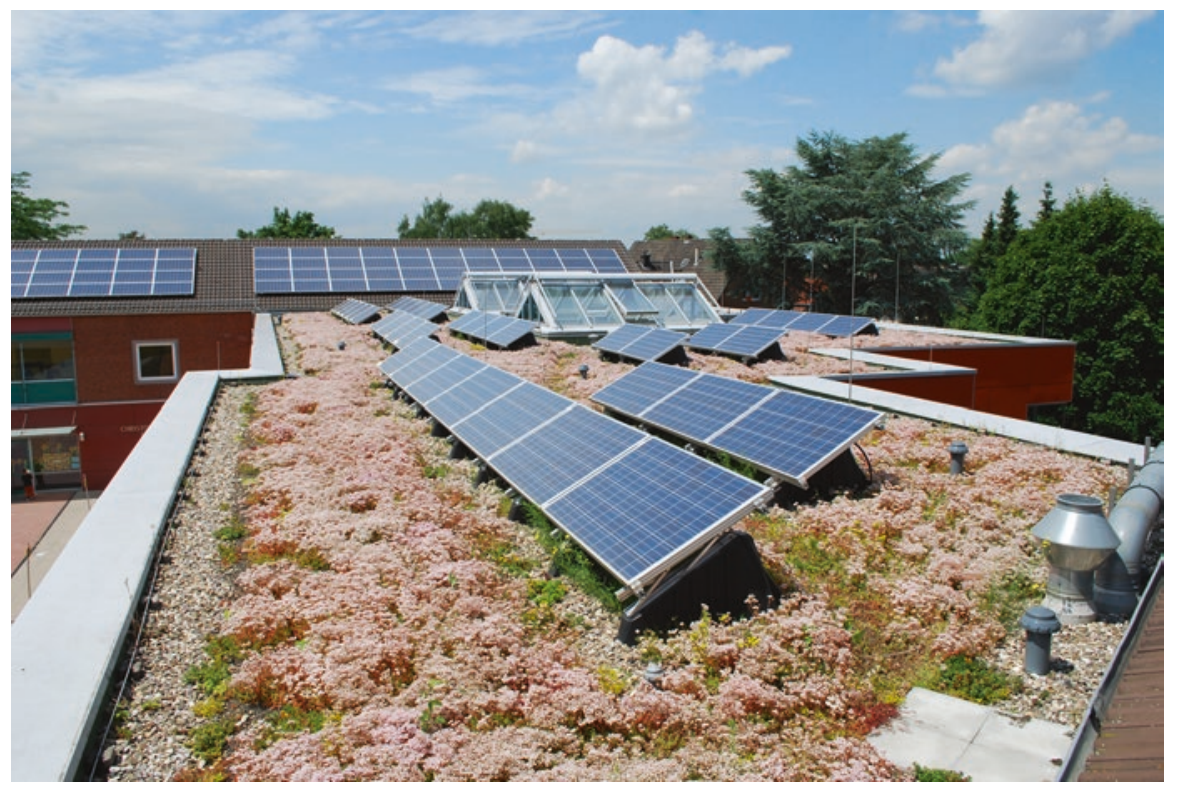

Fig. 10.11 Energy-Greenroof in Germany (Source Gunter Mann, Optigrün AG) 
substrate provides the ballast required to keep photovoltaic (PV) panels weighted on the roof. The evapotranspiration of plants and substrate keeps solar panels cool and can increase their productivity rate by up to $20 \%$ (Mann, 2013). This result refers to the decrease in solar panels' productivity when operating at air temperatures over $25{ }^{\circ} \mathrm{C}$. Compared with blackroofs, vegetated roofs reduce reflected solar radiation and therefore heating effects for the solar panels by up to $40{ }^{\circ} \mathrm{C}$ (BUND 2008).

Demand for dense urban development and the opportunity to sustainably retrofit our existing building stock clearly points towards green roof and wall technologies becoming an automatic part of this process. Designed in an integrative and inclusive way, these multi-beneficial nature-based solutions offer an attractive Return On Investment (ROI) as well as many social and economic benefits (Government of the Netherlands 2013).

\subsubsection{Disservices of Green Building Technology}

Green buildings offer multiple benefits for investors, communities, environment and nature. However, it is important to take into consideration the potential disservices of this technology, even if they seem to be marginal or they are just disadvantageous for specific stakeholders (Baggethun and Barton 2013).

Green roofs and especially living walls may have a higher investment price compared to the majority of traditional building envelope technologies. Nevertheless, they provide a significantly higher benefit value, a study undertaken in Hongkong (Peng and Jim 2015) showed a Return of Invest time of 6.8 years for extensive and 19.5 years for intensive green roofs taken a 40-years lifetime into consideration. Policy schemes, incentives by the state and a broader transfer of benefits into financial terms can significantly change the cost-benefit calculation (Bianchini and Hewage 2012).

Green roof and wall technologies can also require more frequent maintenance than traditional facades and roofs. Especially in the first one or two years after installation during the establishment period of the ecosystem - the lack of proper care can lead to poor results and unhappy customers (Magistrat der Stadt Wien 2015; Mann 2015).

In contrast to living walls, providing cooling effects for public due to their close distance to street spaces and ground level, green roofs cool on roof level only and extensive roofs don't cool effectively during heatwaves (Rittel et al. 2011). Some authors state a missing acceptance of green walls near windows and consider irrigation needs of living walls not as a contribution to the local climate but as a lack of resource efficiency (Rittel et al. 2011; Mann 2015).

And finally, the fear of insects, rodents, etc.: human biophobia in general is something to take into consideration when applying these technologies. Studies show, that co-creation and co- implementation can help to create high levels of citizen acceptance and identification to overcome potential fears (Davies 2015).

Unfortunately, there is still a lot of incorrect information about other disservices. One of the typical examples is that green roofs are a hazard for waterproofing. It is the opposite, because green roofs protect, thus considerably prolong the lifetime of waterproofing (Pfoser 2013). 


\subsection{Technology Versus Biodiversity? Or Technology Delivering Biodiversity?}

There is often a perception that technology within the built environment acts against biodiversity. However, the development of green roof and wall technologies has always been firmly based in an ecological approach (Mann 1996). Since the birth of the green roof and wall movement in Germany, Switzerland and Austria, delivering nature has been central to the development of these industries. Fortunately, these industries have also developed guidelines and standards over the last 30 years to ensure the delivery of ecological and biodiversity benefits:

Technical standards for green roofs have been published regularly since 1990 such as the German FLL Guidelines (FLL 2000; 2008; 2011), Austrian ÖNORM L1131 (ON 2010) and the Swiss Norm SiA 312 (SIA 2013).

Traditionally built green walls, focusing on climbing plants and their use, have had their official FLL Guideline since 2000 (FLL 2008). In 2013, Vienna published their first living wall guideline followed by a second edition in spring 2017 (Magistrat der Stadt Wien 2017). At green roof level, there are point system models to evaluate the quality of the installed roof and the quality of products, including biodiversity aspects in the annex of ÖNORM L1131 (ON 2010).

Common building certification standards such as LEED and BREEAM have begun to include nature-based solutions and rainwater management in their scoring systems (BREEAM 2016), but the level of detail and possibilities for vegetation technologies is still too limited to have a significant high quality impact, experts involved in this Article say. Nevertheless, there are some certified pilot buildings in Europe dedicated to nature and supporting specific species, for example the 3 level Green House Project in Budapest, see Fig. 10.12. (Skanska 2012).

Green roof and wall experts know that diversity in structures and species on buildings generates long-term ecological stability and therefore can also reduce maintenance requirements once the roof or wall is established. All green roof and wall solutions implicitly provide different habitat functions for their bird and insect users (Mann 1994), and contribute in some way to the urban ecological habitat network, serving as stepping stones for species such as insects and birds as do parks at ground level (Mann 1998) (Fig. 10.13).

Moreover, there is the potential to deliver targeted specific biodiversity measures. The more detailed the local urban nature development strategies and programmes are the more customised service implementation projects can deliver. Nature conservation or ecological compensation projects can be located at roof level too, for example the orchid habitat conservation roof in Switzerland (Brenneisen 2002) or the 4 hectare biodiverse green roof on a shopping mall in Basel (Brenneisen et al. 2010, see Fig. 10.14).

Extensive green roofs by their technological constraints can provide opportunities to create specific habitats, especially those associated with dry grassland communities. Whilst there has been a focus on "productising" green roof technologies to meet the construction industry's need for homogeneity, over the last 20 years, 
Fig. 10.12 LEED

Platinum certified "Green

House" Budapest, biodiverse hybrid green roof 7 th floor (Source:

Peter Dezsényi)
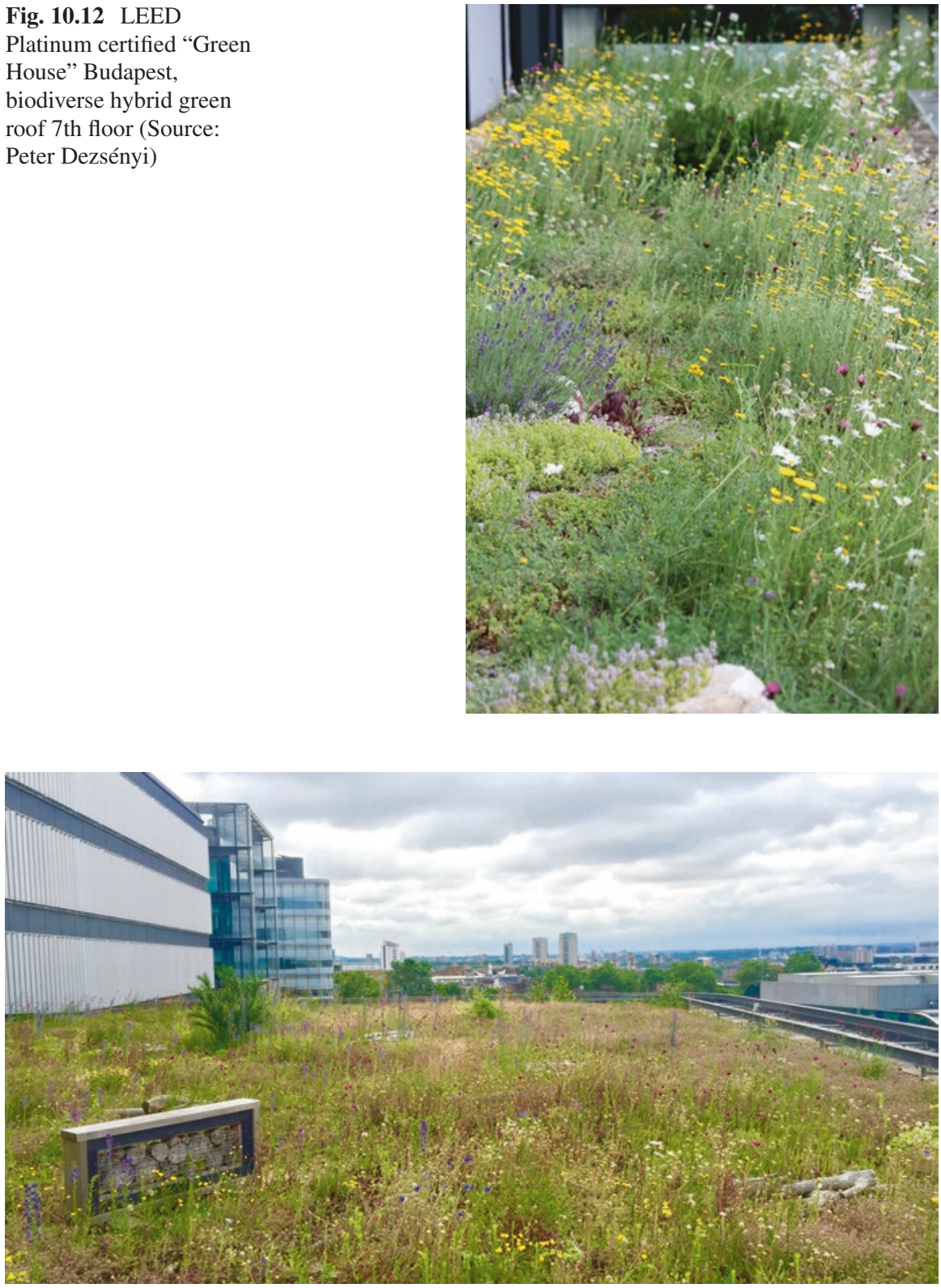

Fig. 10.13 Wildflower roof with insect hotel in London (Source: Dusty Gedge)

approaches have been developed to target the replication of ecological circumstances at ground level. This approach was initially started in Switzerland, where policies at local level were developed (Brenneisen et al. 2010). 


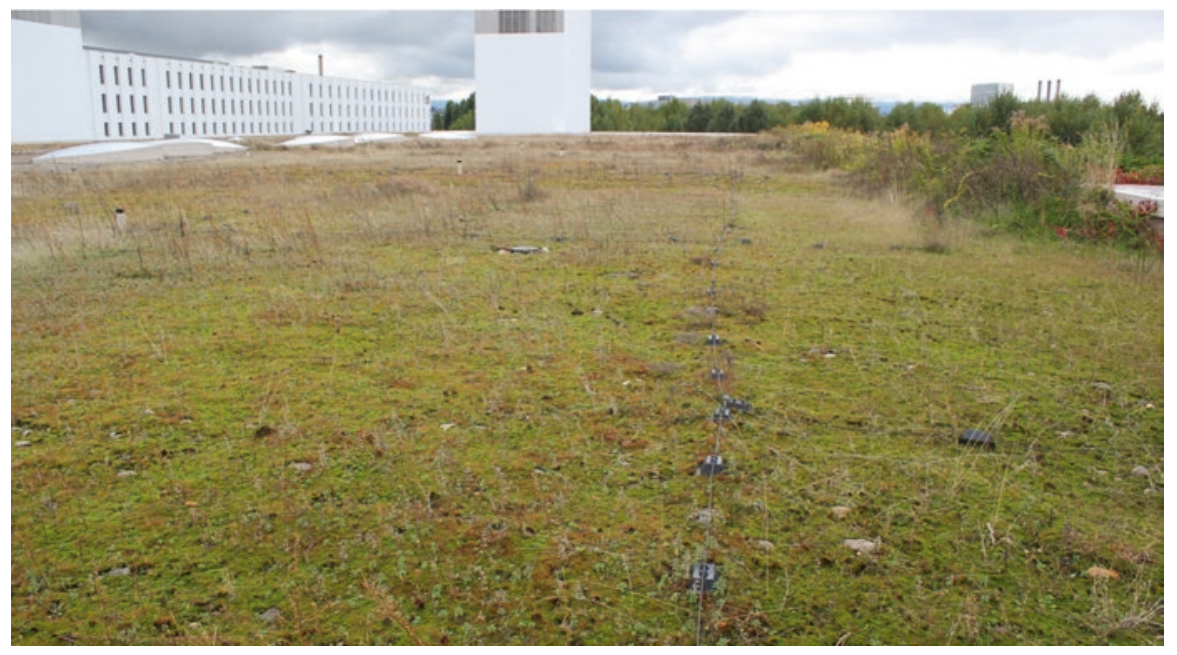

Fig. 10.14 A 4 hectare biodiverse green roof on a shopping mall in Basel (Source: Péter Dezsényi)

These policies targeted the need to create dry grassland communities at roof level. This approach was embraced in London (see Fig. 10.14) and now provides the basis of the planning approach to extensive green roofs in the UK capital (Greater London Authority 2008).

The good and bad implementation experiences with green roofing policies in Switzerland, the UK, and also in Austria have shown that extensive green roof technologies should be implemented in combination with ecological performance criteria and their continuous assessment (comment by the authors of this article).

Scientists from all over the world have been monitoring various types of green roofs and walls for several decades, surveying their ecological development and performance. Their knowledge has resulted in ecological principles for designing biodiverse green roofs, implemented in the Swiss green roof standard $\mathrm{SiA}$ 312 (SIA 2013) and a free online guideline, providing best practice examples to support invertebrates at roof level, published by the Invertebrate Conservation Trust (Buglife 2009) in the UK. This guideline and the launch of the National Pollinators Support Strategy UK, including the urban context (Department for environmental and rural affairs UK 2014) have led to a certain number of projects, in particular to support urban pollinators such as wild bees (GEDGE, D.; GRANT, G. GREENINFRASTRUCTURECONSULTANCY).

There are numerous projects across Europe and elsewhere in the world where biodiversity has been delivered at roof and wall level (URBANHABITATS 2006). There is, however, a general perception within the nature conservation community that these technologies are ecologically limited. This perception needs to be challenged and transformed so that in co-creation and co-operation with citizens, municipalities and planners across Europe approaches can be developed to ensure that nature-based solutions on the building envelopes do deliver biodiversity at the local and regional level. 


\subsection{Nature Provides the Power to Re-wire the City}

Leading European cities such as London, Vienna, Budapest, Copenhagen, Malmö and Paris are setting strategies and implementing policies in line with green infrastructure and biodiversity, encouraging nature-based solution investments in the urban realm (e.g., Greater London Authority 2016; Magistrat der Stadt Wien 2015). Nevertheless, it is a long-term, complex process, as participants at the 1st European Urban Green Infrastructure Conference (EUGIC), held in Vienna, in 2015 stated:

"Green infrastructure in the urban agenda is currently about plumbing, it is necessary to share knowledge (...)",

commented Juliet Lindgren of Malmö City Architecture Department.

"But the positive feedback of people makes you believe that you are doing the right thing",

her colleagues Jürgen Preiss from Vienna City and Peter Massini from the Greater London Authority added (EUGIC 2015).

Certain implementation barriers such as technical knowledge gaps, missing internal collaboration links between different municipality departments (e.g., urban greening and water) and a current absence of strong communication strategies towards citizens were also identified at the EUGIC conference.

A growing number of small to mega scale cities in Europe and beyond have been already setting out their green infrastructure strategies, followed by legislation processes and funding in regards to green roof and walls, e.g., the city of Hamburg (Behörde für Umwelt und Energie 2015). Some cities are already by far advanced and could be recognized as frontrunners, e.g., Green Capital award winning VictoriaGasteiz in Spain.

A clear knowledge gap and barrier to successfully mainstreaming of green infrastructure was identified in quantitative and qualitative, integrated short- and long term monitoring data of all considerable economic, ecologic and societal benefits and disservices of strategic larger scale nature-based solution implementation in Europe. The European Commission has therefore launched a rich bundle of Horizon 2020 calls, especially call SCC-02-2016-2017 demonstrating innovative nature-based solutions in cities, fostering demonstration and implementation actions, is expected to create a significant impact on implementation, research and communication.

On the other hand, the way cities will approach the challenge are context-specific: starting by recognising international frameworks and targets (IEEP 2011), followed by national specific strategies/governance plans (Buijs et al. 2016) complemented by an analysis of local target challenge areas resulting in specific implementation plans and monitoring systems (Madueira et al. 2011) and creation of a common knowledge base on green infrastructure existing stock and potentials of implementation in certain built structures (e.g., Urban Green Stock and potential Cadastre of the City of Vienna ${ }^{1}$ ).

\footnotetext{
${ }^{1}$ https://www.wien.gv.at/umweltschutz/umweltgut/index.html
} 
Fig. 10.15 Birds nesting on an extensive green roof in Germany (Source:

Gunter Mann)

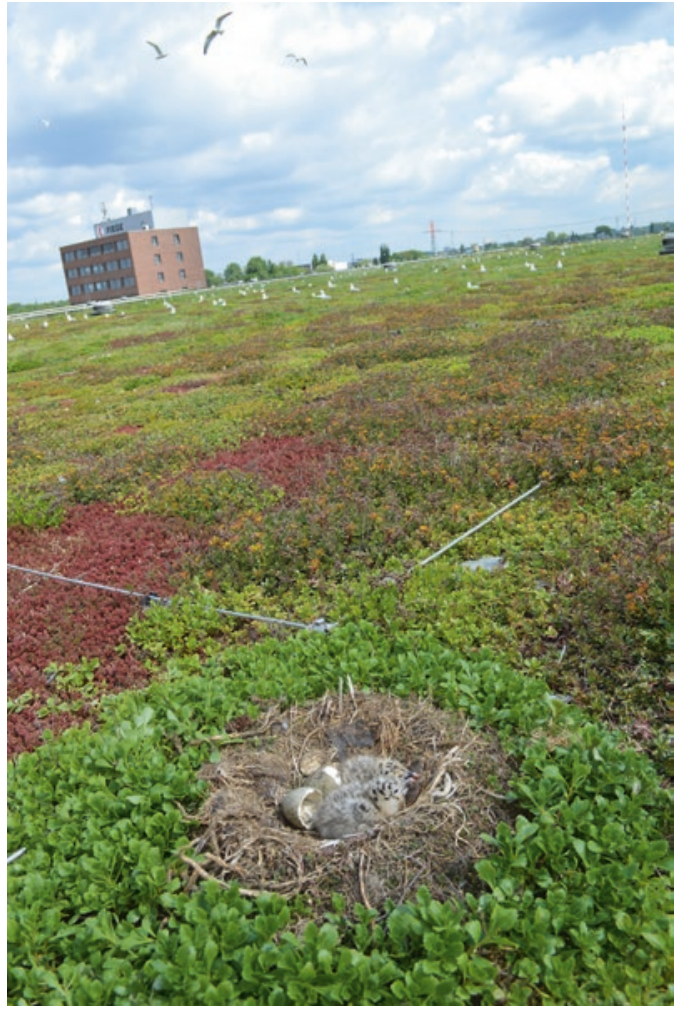

An understanding of general and local nature-based solutions state of the art and technology readiness is crucial (Derzken et al. 2015) resulting in targeted planning and implementation methods (Davies 2015), respecting the overall goal to create a functional, interlinked green infrastructure network (Hansen et al. 2016) in respect of ecological (Elmquist et al. 2015), economical (Peng and Jim 2015) and societal (Baggethun and Barton 2013) maximised impact (Fig. 10.15).

Nature has the power to re-wire the city, delivering multiple benefits across the sustainability, ecological and well-being agendas. This paper has shown the innovative capacity and impact with nature-based solutions on cities buildings:

- Green roofs and green walls are technologies classified as nature-based solutions in the context of urban green infrastructure. There is an active European market in the available technology

- The vision of cities resilient to climate change can only be accomplished by choosing "green over grey"

- Many publications on the measurable public and private benefits of investing in urban green are available 
- Certain clever incentives of governments, such as split waste water taxation in Germany, could speed up implementation by generating attractive and simple business cases and Return On Investment (ROI)

- Policy and legislation should be closely tied to ecological performance and quality benchmarks; existing evaluation models could be used

- Financial barriers such as higher installation and maintenance costs, technical barriers like retrofitting, and knowledge barriers in planning and legislation currently exist

- Trendsetters have recognized the potential of ecologically improved technologies for green roof and living walls that deliver biodiversity

We have shown how urban greening helps to keep cities cool in heat waves, to manage surface water flooding, to improve air quality as well as to provide habitats for species. Green infrastructure offers an attractive economic Return On Investment (ROI) and a range of other benefits to society, such as connection with nature, and mental and physical health.

High quality green infrastructure can also reduce noise pollution, a major cause of stress for city dwellers. Greening a building can help cut heating and cooling costs too, saving energy and other resources.

Green cities give better quality of life, meaning healthier, happier citizens, higher productivity at work and a reduction in absence from work due to illness.

This paper has focused on the microclimate benefits of integrating high quality green infrastructure as part of adapting cities to climate change. It has explained

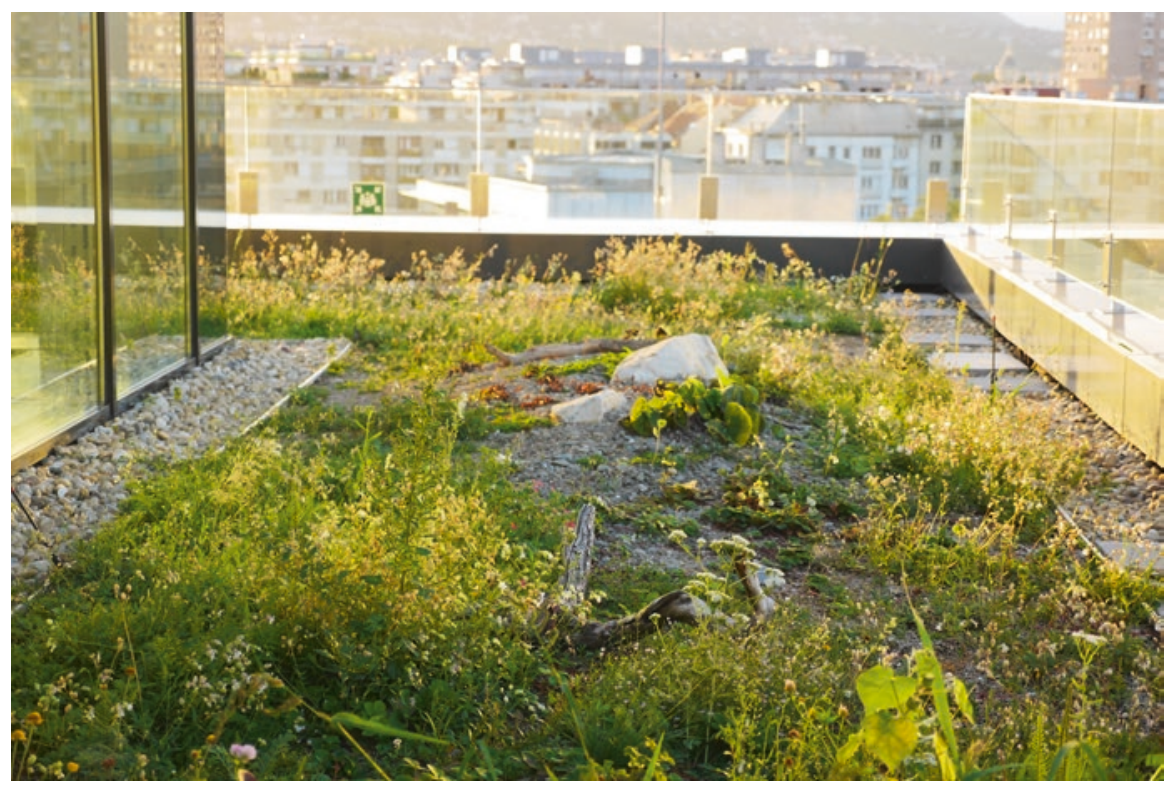

Fig. 10.16 A new and old concept for Biodiversity: LEED Platinum certified "Green House" Budapest, biodiverse hybrid Green Roof 7th floor (Source: Peter Dezsényi). 
through best practise examples how green roofs and green walls designed for nature can contribute to urban biodiversity networks. And it has shown how cities designed with nature-based solutions can provide the ecosystem services needed for natural, healthy and resilient cities in the twenty first century (Fig. 10.16).

\section{References}

Austria Standards Institute ON (2010) Begrünung von Dächern und Decken auf Bauwerken Anforderungen an Planung, Ausführung und Erhaltung. https://shop.austrian-standards.at/ action/de/public/details/362996/OENORM_L_1131_2010_06_01 Accessed 24 Sept 2016

Baggethun E, Barton D (2013) Classifying and valuing ecosystem services for urban planning. Ecol Econ 86(2013):235-245

Behörde für Umwelt und Energie (2015) Auf die Dächer, - fertig - Grün! Die Hamburger Gründach Förderung http://www.hamburg.de/gruendach/4364756/gruendachfoerderung/. Accessed 30 Sept 2016

Bianchini F, Hewage K (2012) Probabilistic social cost-benefit analysis for green roofs: a lifecycle approach. Build Environ 58(2012):152e162

Brenneisen S (2002) Vögel, Käfer und Spinnen auf Dachbegrünungen-Nutzungsmöglichkeiten und Einrichtungsoptimierungen. Geografisches Institut Basel/Baudepartment des Kantons Basel Stadt

Brenneisen S et al (2010) Ökologischer Ausgleich auf dem Dach: Vegetation und bodenbrütende Vögel. Zürcher Hochschule für angewandte Wissenschaften, Zürich

Buglife - Invertebrates Conservation Trust (2009) Creating green roofs for invertebrates. https:// www.buglife.org.uk/sites/default/files/Creating\%20Green $\% 20$ Roofs $\% 20$ for $\% 20$ Invertebrates_Best\%20practice\%20guidance.pdf. Accessed 24 Sept 2016

Buijs A et al (2016) Innovative Governance of Urban Green Spaces-Learning from 18 Innovative examples across Europe, GREEN SURGE PROJECT, Deliverable 6.2

BUND; Bund für Umwelt und Naturschutz Deutschland (2008) Auf einem Dach: Begrünung und Photovoltaik. http://www.bund.net/nc/service/oekotipps/detail/artikel/auf-einem-dachbegruenung-und-photovoltaik/ Accessed 24 Sept 2016

Caroles J for Lux Research (2015) http://www.luxresearchinc.com/news-and-events/pressreleases/read/innovation-will-drive-costs-green-roofs-and-walls-28-2017. Accessed 24 Sept 2016. http://www.greenroofs.com/blog/tag/building-integrated-vegetation-redefining-the-landscape-or-chasing-a-mirage/. Accessed 24 Sept 2016. https://portal.luxresearchinc.com/ research/report_excerpt/17494. Accessed 24 Sept 2016

Davies C (2015) Green Infrastructure Planning and Implementation: the Status of European green space planning and implementation based on an analysis of selected European city-regions, GREEN SURGE PROJECT, Deliverable 5.1

Department for Environmental Food \& Rural Affairs UK 2014 The National Pollinator Strategy: for bees and other pollinators in England https://www.gov.uk/government/uploads/system/uploads/ attachment_data/file/409431/pb14221-national-pollinators-strategy.pdf. Accessed 25 Sept 2016

Derzken $\mathrm{M}$ et al (2015) Green infrastructure for urban climate adaptation: how do resident's view on climate impacts and green infrastructure shape adaptation preferences? Landsc Urban Plan 157(2017):106-130

Direction Des Espaces Verts Et De L'environement Paris (2014) Greening Programme of the Mayor of Paris 2014-2020 http://www.paris.fr/duvertpresdechezmoi. Accessed 24 Sept 2016

Elmqvist T et al (2015) Benefits of restoring ecosystem services in urban areas. Curr Opin Environ Sustain 2015(14):101-108

EUGIC, 1st European Urban Green Infrastructure Conference, Vienna (2015) Conference Proceedings http://urbangreeninfrastructure.org/conference-brochure/\#fb0=1. Accessed 24 Sept 2016 
European Climate Adaptation platform (2016) The economics of managing heavy rains and stormwater in Copenhagen - The Cloudburst Management Plan (2016). http://climate-adapt.eea. europa.eu/metadata/case-studies/the-economics-of-managing-heavy-rains-and-stormwater-incopenhagen-2013-the-cloudburst-management-plan. Accessed 24 Sept 2016

European Commission (2012) Europe 2020: Europe's growth strategy ISBN 978-92-79-23972-4

European Commission (2015) Towards an EU research and innovation policy agenda for naturebased solutions \& re-naturing cities. http://www.vhg.org/media/rtf/Kennisbank/2015_0739_ DG_RTD_WEB-Publication_A4_NBS_long_version_20150310.pdf. Accessed 24 Sept 2016

European Commission (2016a) Supporting the Implementation of Green Infrastructure-Final Report http://ec.europa.eu/environment/nature/ecosystems/docs/green_infrastructures/GI\%20Final\%20 Report.pdf?utm_content=buffer6f $1 \mathrm{bb} \& u t m \_$medium $=$social\&utm_source=twitter.com\&utm campaign=buffer\&utm_source=\&utm_medium $=\& u t m \_c a m p a i g n=$. Accessed 24 Sept 2016

European Commission (2016b) Energy Efficiency-BUILDINGS https://ec.europa.eu/energy/en/ topics/energy-efficiency/buildings Accessed 24 Sept 2016

European Environmental Agency-EEA (2012) Urban adaptation to climate change in Europe Challenges and opportunities for cities ISBN: 978-92-9213-308-5

European Federation of Green Roof and Living Wall Associations-EFB (2015) White Paper 2015. http://www.efb-greenroof.eu/EFB_WhitePaper_2015.pdf. Accessed 24 Sept 2016

European Union (2013) Building a Green Infrastructure for Europe. http://ec.europa.eu/environment/nature/ecosystems/docs/green_infrastructure_broc.pdf. Accessed 24 Sept 2016

Fachvereinigung Bauwerksbegrünung e.V. FBB (2016) Ergebnisse der bundesweiten Umfrage zur Förderung von Gebäudebegrünung der FBB 2016. http://www.gebaeudegruen.info/gruen/dachbegruenung/wirkungen-vorteile-fakten/foerderung-2016/?key=1-1. Accessed 27 Sept 2916

Forschungsgesellschaft Landschaftsentwicklung Landschaftsbau e.V. FLL (2000) Fassadenbegrünungsrichtlinie - Richtlinie für die Planung, Ausführung und Pflege von Fassadenbegrünungen mit Kletterpflanzen Artikelnummer: 12020001

Forschungsgesellschaft Landschaftsentwicklung Landschaftsbau e.V. FLL (2008) Richtlinie für die Planung, Ausführung und Pflege von Dachbegrünungen ISBN: 978-3-940122-08-7

Forschungsgesellschaft Landschaftsentwicklung Landschaftsbau e.V. FLL (2011) Richtlinien für die Planung, Ausführung und Pflege von Innenraumbegrünungen, 2011 ISBN: 978-3-940122-25-4

Green Surge (2016) BREEAM Certification UK, Strategic Ecology Framework. http://www. breeam.com/filelibrary/Response-Document/SEF-External-Consultation-ResponseDocument--April-2016-.pdf. Accessed 25 Sept 2016

Government of the Netherlands (2013) Biodiversity - what's it worth to you? 10 good reasons for Biodiversity Action Plans. https://www.youtube.com/watch?v=pYFQt3k_Cks. Accessed 24 Sept 2016

Greater London Authority (2008) Living roofs and walls; technical report: supporting London plan policy. https://www.london.gov.uk/sites/default/files/living-roofs.pdf. Accessed 24 Sept 2016)

Greater London Authority (2016) The London Plan; Spatial development Strategy for London consolidated with alterations since $2011 \mathrm{https} / / / \mathrm{www}$. london.gov.uk/sites/default/files/the_london_plan_malp_final_for_web_0606_0.pdf. Accessed 24 Sept 2016

Hansen R et al (2016) Advanced urban green infrastructure planning and implementation: innovative approaches and Strategies from European cities, GREEN SURGE PROJECT, Deliverable 5.2

Hämmerle F, EFB (2007) Zur Wirtschaftlichkeit von Gründächern. http://www.efb-greenroof.eu/verband/fachbei/Die\%20Wirtschaftlichkeit\%20von\%20Gruendaechern.pdf. Accessed 24 Sept 2016

Institute For Environmental Policy-Ieep (2011) Green infrastructure implementation and efficiency final report: ENV.B.2/SER/2010/0059

Köhler M (2012) Handbuch Bauwerksbegrünung ISBN 978-3-481-02968-5

Korjenic A, Tudiwer D (2016) The effect of living wall systems on the thermal resistance of the façade. Energy and Buildings, Accepted Manuscript, 2016 (Forschungsbericht im Auftrag der Magistratsabteilung 22 der Stadt Wien - 154330/2015: Erforschung von Grünfassaden hinsichtlich deren wärmedämmenden Wirkung mittels flächigen Wärmeflussmessungen)

Madueira $\mathrm{H}$ et al (2011) Green structure and planning evolution in Porto. Urban For Urban Green 10(2011):141-149 
Magistrat der Stadt Wien, Preiss J et al (2015) Urban heat Islands Strategieplan Wien https://www. wien.gv.at/umweltschutz/raum/pdf/uhi-strategieplan.pdf. Accessed 24 Sept 2016

Magistrat der Stadt Wien, Preiss J. et al (2017) Fassadenbegrünungsleitfaden der Stadt Wien, 2. Edition Magistratsabteilung 22 für Umweltschutz der Stadt Wien Status: Not yet published, official date May 2017

Mann G (1994) Ökologisch-faunistische Aspekte begrünter Dächer in Abhängigkeit vom Schichtaufbau. Diplomarbeit Universität Tübingen

Mann G (1996) Die Rolle begrünter Dächer in der Stadtökologie. Biologie in unserer Zeit 5:292-299

Mann G (1998) Vorkommen und Bedeutung von Bodentieren (Makrofauna) auf begrünten Dächern in Abhängigkeit von der Vegetationsform. Dissertation Universität Tübingen

Mann G (2013) SolarGrünDächer. Das Dach zweifach nutzen. Greenbuilding 6

Mann G (2015) Begrünte Dächer als Ausgleichsflächen Stadt und Grün Heft 1/2015

Mann G (2016) Urban farming - natürlich auf Dächern. - Transforming Cities 3. Trialog Publishers Verlagsgesellschaft München

Orsini F et al (2014) Exploring the production capacity of rooftop gardens (RTGs) in urban agriculture: the potential impact on food and nutrition, security, biodiversity and other ecosystem services in the city of Bologna. Springer Science+Business Media Dordrecht and International Society for Plant Pathology 2014

Ottelé M (2011) The Green Building Envelope - Vertical Greening Dissertation, Technical University of Delft, Netherlands ISBN: 978-90-9026217-8

Peng L, Jim C (2015) Economic evaluation of green-roof environmental benefits in the context of climate change: the case of Hong Kong. Urban For Urban Green 14(2015):554-561

Pfoser N (2013) Gebäude Begrünung Energie. Potenziale und Wechselwirkungen. Abschlussbericht. https://www.baufachinformation.de/literatur/Geb\%C3\%A4ude-Begr\%C3\%BCnungEnergie/2013109006683. Accessed 24 Sept 2016

Pitha U (2015) Blooming cityscapes - vegetated technical solutions for liveable and sustainable urban areas focusing on permeable paving systems, green roofs and green walls Habilitationsschrift, University of Life Sciences Vienna (BOKU)

Rittel, Wilke, Heiland (2011) Anpassung an den Klimawandel in städtischen Siedlungsräumen Wirksamkeit und Potenzial kleinräumiger Maßnahmen in verschiedenen Stadtstrukturtypen. Die Natur der Stadt im Wandel des Klimas. CONTUREC (Hrsg)

Robine J et al (2007) Report on excess mortality in Europe during summer 2003. http://ec.europa. eu/health/ph_projects/2005/action1/docs/action1_2005_a2_15_en.pdf. Accessed 24 Sept 2016

Scharf B, Pitha U, Oberarzbacher S (2012) Living walls: more than scenic beauties, IFLA World Congress Cape Town. http://www.academia.edu/6649534/Living_Walls_more_than_scenic_ beauties. Accessed 24 Sept 2016

Schweizerischer Ingenieur- und Architektenverein sia (2013) Begrünung von Dächern, SIA 312, SN 564312. http://shop.sia.ch/normenwerk/architekt/sia\%20312/d/D/Product. Accessed 25 Sept 2016

Skanska (2012) Green House, Budapest. http://group.skanska.com/projects/57306/Green-HouseBudapest. Accessed 25 Sept 2016

Thönessen M (2002) Elementdynamik in Fassaden begrünendem Wilden Wein Köllner Geografische Arbeiten, Heft 78

Thönessen M (2006) Staubfilterung und immisionshistorische Aspekte am Beispiel fassadenbegrünenden Wilden Weins (Parthenocissus tricuspidata). Originalarbeit, ecomed Verlag, Landsberg-Tokyo-Mumbai-Seoul-Melbourne-Paris

Unep-Dtie Initiative (2016) Cities and Buildings Projects Online here. http://www.unep.org/SBCI/pdfs/ Cities_and_Buildings-UNEP_DTIE_Initiatives_and_projects_hd.pdf. Accessed 24 Sept 2016

United Nations (2014) Highlights of world urbanisation prospects. https://esa.un.org/unpd/wup/ Publications/Files/WUP2014-Highlights.pdf. Accessed 24 Sept 2016

URBANHABITATS.org (2006) Green Roofs and Biodiversity, Urban Habitats, Volume 4, Number 1 ISSN 1541-7115. http://www.urbanhabitats.org/v04n01/urbanhabitats_v04n01_pdf.pdf. Accessed 24 Sept 2016 
Verband Für Bauwerksbegrünung Österreich-VfB (2013) Forschungsbericht Projekt GrünStadtKlima, Grüne Bauweisen für die Städte der Zukunft. http://www.gruenstadtklima.at/ download/leitfaden_GSK.pdf. Accessed 24 Sept 2016

\section{Project Links}

Definition of Nature Based Solutions European Commission 2016. https://ec.europa.eu/research/ environment/index.cfm?pg=nbs. The economics of managing heavy rains and stormwater in Copenhagen: http://www.e-pages.dk/tmf/132/http://www.klimatilpasning.dk/media/665626/ cph_-_cloudburst_management_plan.pdfhttp://klimakvarter.dkhttp://base-adaptation.eu/implementation-copenhagen-cloudburst-strategy-copenhagen-denmark. Victoria-Gasteiz: Winner of the European Green Capital Award: http://ec.europa.eu/environment/europeangreencapital/wpcontent/uploads/2011/04/European-Green-Capital-Award-2012-13-nuevo-estandar.pdf

SCC-02-2016-2017 Demonstrating innovative Nature Based Solutions in Cities. http://ec.europa. eu/research/participants/portal/desktop/en/opportunities/h2020/topics/scc-02-2016-2017. html. GREENINFRASTRUCTURECONSULTANCY GEDGE, D., GRANT, G.: Projects for Pollinators. www.greeninfrastructureconsultancy.com

Open Access This chapter is licensed under the terms of the Creative Commons Attribution 4.0 International License (http://creativecommons.org/licenses/by/4.0/), which permits use, sharing, adaptation, distribution and reproduction in any medium or format, as long as you give appropriate credit to the original author(s) and the source, provide a link to the Creative Commons license and indicate if changes were made.

The images or other third party material in this chapter are included in the chapter's Creative Commons license, unless indicated otherwise in a credit line to the material. If material is not included in the chapter's Creative Commons license and your intended use is not permitted by statutory regulation or exceeds the permitted use, you will need to obtain permission directly from the copyright holder. 